\title{
ARTIKELEN
}

\section{De relatieve betekenis van de Grondwet voor de wetgever}

\author{
Een beschouwing over de Nederlandse juridische \\ grondwetscultuur in de twintigste eeuw ${ }^{*}$
}

J.J.J. Sillen

\section{Inleiding}

'Wat is de betekenis van de Grondwet voor de wetgever?', dat is de vraag die centraal staat in dit nummer van RegelMaat. Doorgaans wordt bij de beantwoording van die vraag gewezen op het bindende karakter van de Grondwet, maar ook op twee kenmerken van onze Grondwet die haar betekenis voor de wetgever relativeren: dat zij veel zaken naar de wetgever verwijst en dat zij de rechter verbiedt de grondwettigheid van wetten te beoordelen. Vervolgens luidt dan het antwoord dat de Grondwet veel vrijheid aan de wetgever biedt. ${ }^{1}$ Hoewel ik die conclusie deel, wordt met die redenering volgens mij niet het hele verhaal verteld. Wat mist is hoe in Nederland in het algemeen over de juridische betekenis van de Grondwet wordt gedacht. Ik noem dat de Nederlandse grondwetscultuur. Ik verwijs met die term dus niet naar de maatschappelijke betekenis van de Grondwet: haar mogelijke rol als inspirerend of samenbindend document. ${ }^{2}$ In plaats daarvan doel ik met die term op de juridische betekenis van de Grondwet: wat is haar rol als norm? De genoemde veelvuldige delegatie aan de wetgever en het toetsingsverbod zijn volgens mij uitdrukkingen van die cultuur.

In deze bijdrage staat dus de Nederlandse grondwetscultuur centraal. Zij bestaat naar mijn oordeel uit drie, nauw met elkaar verbonden, elementen. Ten eerste is dat het bindende karakter van de Grondwet voor de wetgever. Hoewel die binding onder Nederlandse staatsrechtjuristen nu vanzelfsprekend is, ${ }^{3}$ was zij dat aan het begin van de vorige eeuw niet. Ik laat dat zien in paragraaf 2. De wijze waarop toen het debat over de bindende kracht van de Grondwet is beslecht, vormt ook

* Deze bijdrage is mogelijk gemaakt door een subsidie van het Fonds Staatsman Thorbecke.

1 Vgl. P.P.T. Bovend'Eert, J.L.W. Broeksteeg, C.N.J. Kortmann \& B.P. Vermeulen, Kortmann. Constitutioneel recht, Deventer: Wolters Kluwer 2016, p. 84.

2 Zo bijv. T. Barkhuysen e.a., De Nederlandse Grondwet geëvalueerd: anker- of verdwijnpunt, Alphen aan den Rijn: Kluwer 2009, die de term grondwetscultuur gebruiken voor de mate waarin een grondwet is gegrondvest op 'grote en meeslepende gedachten' (p. 18) of een 'maatschappelijke functie' vervult (p. 20).

3 D.J. Elzinga, R. de Lange \& H.G. Hoogers, Van der Pot. Handboek van het Nederlandse staatsrecht, Deventer: Kluwer 2014, p. 199; Kortmann/Bovend’Eert e.a. 2016, p. 25. 
nu nog de achtergrond van de Nederlandse grondwetscultuur. Zij werkt door in twee andere elementen van die cultuur, namelijk de dominante opvatting over hoe de Nederlandse Grondwet hoort te worden uitgelegd en het goeddeels ontbreken van een visie op welke normen in de Grondwet thuishoren. Ik bespreek deze twee elementen respectievelijk in paragraaf 3 en 4 . Ik sluit af met een korte conclusie in paragraaf 5 .

Het doel van deze bijdrage is daarmee het beschrijven van de moderne Nederlandse grondwetscultuur vanuit historisch perspectief. Daarbij heb ik geprobeerd de in Nederland gangbare opvattingen weer te geven. ${ }^{4}$ Wat ik hier presenteer, valt dus niet (noodzakelijk) samen met mijn opvattingen over wat de Nederlandse Grondwet betekent of zou moeten betekenen.

\section{Het bindende karakter van de Grondwet voor de wetgever}

Vanaf 1848 tot ongeveer de jaren tachtig van de negentiende eeuw speelde de Grondwet de hoofdrol in de Nederlandse staatkundige ontwikkeling. Conservatieven, liberalen en antirevolutionairen streden in die periode om de juiste betekenis van de nieuwe grondwetsbepalingen die de verhoudingen tussen Koning, ministers en volksvertegenwoordiging beheersten. Het was het tijdvak van de 'constitutionele politiek'. ${ }^{5}$ Vanaf de jaren tachtig van de negentiende eeuw stond vast dat die strijd door de liberalen was gewonnen. De ministeriële verantwoordelijkheid, die de macht van de Koning ten opzichte van de ministers in belangrijke mate beteugelde, was vast onderdeel geworden van het politieke bedrijf, net als de gewoonte dat de Tweede Kamer zich van een onwelgevallige minister kon ontdoen door diens begroting te verwerpen.

De vraag naar de grondwettelijke verdeling van bevoegdheden tussen Koning, ministers en volksvertegenwoordiging kwam vervolgens langzaam in de schaduw te staan van de grenzen die de Grondwet aan deze ambten stelde om zaken naar eigen inzicht te regelen. In het bijzonder bleek de Grondwet een sta-in-de-weg voor uitbreiding van het actief (mannen)kiesrecht en voor de subsidiëring van het bijzonder onderwijs. ${ }^{6}$ De Staatscommissie-Heemskerk werd in 1883 belast met het voorbereiden van herzieningsvoorstellen om deze belemmeringen uit de weg te ruimen. Het lukte haar een compromis te bereiken over de kiesrechtuitbreiding, maar niet over de financiële gelijkstelling van het bijzonder en het algemeen onderwijs. Toen de confessionelen bij de behandeling van de herzieningsvoorstellen tegen álle herzieningsvoorstellen dreigden te stemmen als niet óók de gelijkstelling van bijzonder onderwijs werd geregeld, ${ }^{7}$ werd duidelijk dat onder druk ook de Grondwet vloeibaar wordt. De confessionele steun was noodzakelijk voor

4 Ik pretendeer dus ook niet dat in de twintigste eeuw niet óók andere opvattingen te beluisteren waren.

5 H. te Velde, 'Constitutionele politiek', in: N.C.F. van Sas \& H. te Velde (red.), De eeuw van de Grondwet. Grondwet en politiek in Nederland, 1798-1917, Deventer: Kluwer 1998, p. 147-181.

6 Daarnaast klonk de roep om een adequate rechtsbescherming tegen de overheid.

7 Het zogenoemde 'non possumus'. 
het slagen van de alom dringend noodzakelijk geachte herziening. Om haar niet in gevaar te brengen, sprak een Kamermeerderheid uit dat de Grondwet zich - in weerwil van haar jarenlange andersluidende opvatting - niet tegen subsidiëring van het bijzonder onderwijs verzette. ${ }^{8}$ Zo werd de grondwetsherziening van 1887 veiliggesteld, terwijl de gewijzigde interpretatie van de Grondwet de weg vrijmaakte voor de Lager Onderwijswet van 1899, die de subsidiëring van het bijzonder onderwijs daadwerkelijk regelde.

Met deze episode uit de staatsrechtelijke geschiedenis begon een periode waarin tijdgenoten erkenden dat de wetgever de letter van de Grondwet veelvuldig negeerde. Die opvatting werd breed gedeeld. Het advies van de Raad van State over de wetsvoorstellen tot invoering van administratieve rechtspraak uit 1904 is daarvoor illustratief. Nadat de Raad had vastgesteld dat deze ongrondwettig waren, verzuchtte hij dat 'de ondervinding leert, dat een beroep op de Grondwet niet gemakkelijk ingang vindt, wanneer groote belangen eene zoogenaamde breede uitlegging wenschelijk maken'. Daarop besloot hij tevens uit te leggen welke niet-juridische argumenten óók tegen het wetsvoorstel pleitten. ${ }^{9}$

Diverse staatsrechtjuristen deelden het oordeel van de Raad van State dat de wetgever de Grondwet in de praktijk maar beperkt in acht nam. Opvallend was echter dat die vaststelling hen er niet toe bracht de noodklok te luiden. Zo vestigde in 1901 A.F. de Savornin Lohman (1837-1924) in Onze Constitutie de aandacht op de 'blijkbare verkrachtingen van de letter der bestaande grondwet' die in de recente geschiedenis hadden plaatsgevonden. Toch was van grondwetsverachting door de wetgever volgens hem geen sprake. De feiten dwongen de wetgever nu eenmaal soms tot zulke grondwetsschendingen: 'Handhaving van de letter der grondwet zou ons land meer dan eens zeer groot ongerief hebben veroorzaakt.' Daarmee zei hij overigens niet dat deze ongrondwettige wetten geheel onproblematisch waren. Hij vreesde met name dat de 'eerbied' voor de wet onder deze praktijk te lijden had: 'Als de wetgever, die toch de handhaving der grondwet bezweert, zóó handelen moet, waarom zou dan het volk meer "eerbied" hebben voor die wet[?]' Daarom was het zaak 'door tijdige grondwetherziening, de grondwet en alle wetten in overeenstemming te brengen met de steeds voortgaande rechtsontwikkeling. ${ }^{10}$

In 1907 stelde J. Oppenheim (1849-1924) de betekenis van de Grondwet voor de wetgever aan de orde in zijn rede De suprematie van de Grondwet: 'Er zijn uit het Nederlandsche Staatsblad een heele reeks van wetsbepalingen op te delven, die een zwaren dobber zouden hebben, werden zij uit het oogpunt harer grondwettigheid in Themis' weegschaal gewogen. ${ }^{11}$ Hij staafde die stelling met een hele reeks voorbeelden. ${ }^{12}$ Net als Lohman meende echter ook hij dat dit niet per se problematisch was. Niet de praktijk maar de verzwaarde wijzigingsprocedure van de

$8 \quad$ Kamerstukken II 1886/87, 91, nr. 4, p. 5.

9 Kamerstukken II 1905/06, 63, nr. 2, p. 5. Staatsraad Asser schreef een minderheidsnota, waarin hij stelde dat de voorstellen wel verenigbaar waren met de Grondwet (p. 13-14).

10 A.F. de Savornin Lohman, Onze Constitutie, Utrecht: Kemink \& Zoon 1901, p. 45.

11 J. Oppenheim, 'De suprematie der Grondwet', Rechtsgeleerd Magazijn 1907, p. 74.

12 Oppenheim 1907, p. 75-76. 
Grondwet was volgens hem de oorzaak van het probleem: 'Het is zelfbedrog in de hechtheid van den waarborg [van de grondwetswijzigingsprocedure; JS] te gelooven, als de wrevel over instellingen waaraan de natie is ontgroeid, maar die door de kracht van een grondwetsartikel blijven voortbestaan, zijn hoogtepunt heeft bereikt.' ${ }^{13}$ Oppenheim pleitte daarom zelfs voor het opheffen van het verschil tussen wet en Grondwet:

'De suprematie, die wordt ontleend aan een papieren voorschrift, 't welk de normen, die de fundamenten zijn van al het andere, waarop het gebouw van den staat rust, kunstmatig van de andere scheidt, is de ware niet. Neen, hunnen suprematie moeten deze normen ontleenen hieraan, dat zij bevrediging schenken aan - in harmonie zijn met hetgeen omgaat in het leven en geweten van het volk, en dat dit volk de wetgeving legt in eerlijke, vertrouwde, onbaatzuchtige handen.' ${ }^{14}$

Klinken de opvattingen van Lohman en Oppenheim in onze oren radicaal, zij waren het toonbeeld van gematigdheid in vergelijking met de denkbeelden van de Groningse, en later Leidse, hoogleraar staatsrecht H. Krabbe (1857-1936). In een tweetal geruchtmakende bijdragen - 'De heerschappij der Grondwet' en, vooral, Ongezonde lectuur - bond hij de strijd aan met de Grondwet. Het eerste stuk opende met de zin: 'Het feit is geboekstaafd dat de wet, welke zich als Grondwet betitelt, van al onze wetten het minst wordt nageleefd. ${ }^{15}$ Ook voor hem lag de oorzaak daarvan in de verzwaarde wijzigingsprocedure van de Grondwet. Deze leidde ertoe dat de Grondwet vaak niet aansloot bij het actuele, individuele rechtsbewustzijn van een meerderheid van de burgers, terwijl dat rechtsbewustzijn volgens hem de enige grondslag van het geldende recht was en kón zijn. Voor zover de Grondwet niet aansloot bij het rechtsbewustzijn, was zij volgens hem geen geldend recht. ${ }^{16}$ In zijn brochure 'Ongezonde lectuur' schreef hij:

'Wat voor alle recht thans als conditio sine qua non zijner heerschappij geldt, t.w. dat het wortelen moet in het rechtsbewustzijn eener meerderheid, dat moogt gij voor het constitutioneele recht niet ter zijde stellen. Ja, gij kùnt dat en misschien zult gij 't doen; maar dan geschiedt dat wederrechtelijk, want nog eens: gij mist het recht de doorwerking van het rechtsbewustzijn eener meerderheid te belemmeren. ${ }^{17}$

Krabbes betoog gaf aanleiding tot felle debatten en zijn rechtstheorie stond in de eerste decennia van de twintigste eeuw in het centrum van het wetenschappelijk debat. Zijn radicale opvattingen vonden echter weinig medestanders. ${ }^{18}$

Oppenheim 1907, p. 77-78.

Oppenheim 1907, p. 85.

H. Krabbe, 'De heerschappij der Grondwet', De Gids 1906, p. 371. Zie ook H. Krabbe, 'Ongezonde lectuur', Groningen: J.B. Wolters 1913, p. 28-30.

H. Krabbe, De moderne staatsidee, 's-Gravenhage: Martinus Nijhoff 1915, p. 43-44.

Krabbe 1913, p. 28.

Een uitzondering was R. Kranenburg (1880-1956). 
Oppenheims oproep om het rangverschil tussen wet en grondwet op te heffen, vond meer weerklank. In 1914 stond deze oproep centraal tijdens de vergadering van de Nederlandse Juristen-Vereniging. Maar liefst drie preadviseurs lieten hun licht schijnen over de stelling dat het verschil tussen wet en Grondwet moest verdwijnen. Twee van hen pleitten tegen die stelling, namelijk de Amsterdamse hoogleraar J.A. van Hamel (1880-1964) en de voormalig minister van Justitie J.A. Loeff (1858-1921), en een ervoor, te weten de Groninger hoogleraar Ph. Kleintjes (1867-1938). Daarnaast verschenen er twee 'officieuze' preadviezen, die tegen de stelling pleitten: een van de Utrechtse hoogleraar staatsrecht J. de Louter (1847-1932) en een van de Amsterdamse hoogleraar staatsrecht A.A.H. Struycken (1873-1923). ${ }^{19} \mathrm{Na}$ een verhit debat verwierp de vergadering de stelling met 69 tegen 17 stemmen. ${ }^{20}$ Het was een overwinning voor de visie-Struycken. Deze verwierp de nadruk op het rechtsbewustzijn als enige grondslag van het recht. In plaats daarvan was het recht volgens hem een 'kultuurproduct, waarin zich de invloed der sociaal werkzame krachten in den loop der geschiedenis heeft geopenbaard'. Aan het recht lag volgens hem een compromisgedachte ten grondslag: het moest een evenwicht vinden tussen 'het verleden en het heden, tusschen het behoudende en vooruitstrevende in den mensch [etc.]'. 'Die verzoening is nimmer anders dan een pogen, (...) waaraan geslacht en geslacht, zoekend en tastend, telkens door de ondervinding geleid, zonder ophouden heeft gewerkt.' ${ }^{21}$ De Grondwet moest volgens hem dienovereenkomstig worden behandeld. Zij bevatte geen uitputtende regeling, maar was slechts de 'grondvorm' van het staatsleven. ${ }^{22}$ De wetgever had dat volgens hem goed begrepen toen hij de Grondwet anders toepaste dan haar opstellers hadden beoogd. De wetgever kwam daarmee tegemoet aan 'de rechtscheppende en rechtsvervormende krachten van het volksleven, waarin de Grondwet niet als "juridisch", "deskundig" "uit te leggen" dokument, maar als de uitdrukking van de groote gedachten in bestand en in ontwikkeling van ons staatkundig leven, uit het verleden tot ons gebracht, eene plaats inneemt'. ${ }^{23}$ De totstandkoming van de Lager Onderwijswet van 1899, waartoe een nieuwe uitleg van het onderwijsartikel de weg had geopend, was volgens Struycken dan ook geenszins een voorbeeld van grondwetschending, maar 'een sprekend voorbeeld van behoorlijke toepassing der Grondwet, zich aanpassende aan veranderde toestanden en denkbeelden, onder eerbiediging van hare grondgedachte: de zorg der Overheid voor deugdelijk volksonderwijs'. ${ }^{24}$

Zo was de stand van zaken aan de vooravond van de Eerste Wereldoorlog. Daarna luwde het debat over de betekenis van de Grondwet voor de wetgever, maar ver-

19 Het betoog van De Louter, dat is verschenen in het Utrechtsch Dagblad, komt ter sprake in Handelingen NJV 1914-II, p. 84, maar heb ik niet kunnen vinden. (Ook Van Leeuwen vond het stuk niet terug, zie C.W. van Leeuwen, 'Tussen afschaffen en versterking', TvCR 2014, p. 98, noot 10.) Struyckens 'preadvies' verscheen eerst als een serie artikelen in Vragen des tijds en werd later gebundeld als De Grondwet. Haar karakter en waarde, Arnhem: S. Gouda Quint 1914.

20 Handelingen NJV 1914-II, p. 175.

21 Struycken 1914, p. 23.

22 Struycken 1914 , p. 51.

23 Struycken 1914 , p. 45.

24 Struycken 1914, p. 49. 
stommen deed het niet. Na de Tweede Wereldoorlog laaide de discussie opnieuw op, mede naar aanleiding van het uitblijven van een algehele grondwetsherziening en door twijfels over de grondwettigheid van bepaalde wetten, waaronder wetten die de weg vrijmaakten voor de dekolonisatie. ${ }^{25}$ In 1958 werd het debat op scherp gezet door het proefschrift van J. van der Hoeven (1916-2001): De plaats van de grondwet in het constitutionele recht. ${ }^{26}$ Daarin betoogde hij dat grote delen van de Grondwet, met name de bepalingen die de verhoudingen tussen de belangrijkste politieke ambten regelen en die daaraan bevoegdheden toekennen, geen normatieve kracht hebben of kunnen hebben. Hun verhoudingen en bevoegdheden werden niet door het geschreven recht bepaald, maar door de bestaande feitelijke machtsverhoudingen. ${ }^{27}$ Hoewel Van der Hoevens opvattingen scherp werden bekritiseerd, mede onder verwijzing naar Struycken, ${ }^{28}$ leidde zijn boek wel tot inscherping van de gedachte dat het constitutionele recht zich in belangrijke mate ontwikkelt buiten de Grondwet om. Hoewel de Grondwet nog steeds van belang werd geacht als basisdocument, werd het schrappen van grondwetsbepalingen die deze ontwikkeling konden hinderen, nog meer dan voorheen, een belangrijk uitgangspunt bij grondwetsherzieningen. ${ }^{29}$ Voor de algehele grondwetsherziening, die uiteindelijk in 1983 tot stand kwam, was deconstitutionalisering dan ook een van de leidende uitgangspunten. ${ }^{30}$ Toch klonk ook in de jaren zeventig nog de vraag naar het nut van een Grondwet voor de wetgever. Tijdens de parlementaire behandeling van de Nota inzake het grondwetsherzieningsbeleid vroeg het PPR-Kamerlid E.C.M. Jurgens (1935): 'Waarom gaat de regering als vanzelfsprekend ervan uit dat aan een grondwet (...) nog steeds behoefte bestaat?’31 En: 'Waarom is er zoveel inzet voor een herziening, wanneer het enige resultaat een wat opgepoetste Grondwet is, die een even bescheiden rol zal blijven spelen als voorheen?'32

25 Noodwet Indonesië (1948). Zie overigens ook de Grenscorrectiewet (1949) en de Wet bestuursrechtspraak bedrijfsorganisaties (1950).

26 J. van der Hoeven, De plaats van de grondwet in het constitutionele recht (diss. Amsterdam UvA), Zwolle: W.E.J. Tjeenk Willink 1958.

27 Van der Hoeven 1958, p. 41-42.

28 Bijv. F.J.F.M. Duynstee, '(Bespreking van) Johannes van der Hoeven, De plaats van de grondwet in het constitutionele recht', RMThemis 1959, p. 318. Zie J.H.A. Logemann, 'Feit en recht in het staatsleven' (bespreking van J. van der Hoeven, De plaats van de grondwet in het constitutionele recht), Socialisme en democratie 1958, p. 417-430.

29 Daarnaast ontstond de gedachte dat de grondrechten meer aandacht verdienden in de Grondwet. Dat leidde uiteindelijk tot de opname van een uitgebreide grondrechtencatalogus in 1983 . Tegen de tijd echter dat de grondwetsherziening gereed was, was de betekenis van het EVRM voor Nederland sterk toegenomen: de verdragsbepalingen legden in het algemeen meer beperkingen op aan de wetgever dan het nieuwe grondrechtenhoofdstuk.

30 C.A.J.M. Kortmann, De Grondwetsherzieningen 1983 en 1987, Deventer: Kluwer 1987, p. 34 e.v. Deze betwijfelde echter of het resultaat van de grondwetsherziening er inderdaad toe had geleid dat de Grondwet in 1983 minder materiële normen bevatte dan voorheen. Hoewel veel verouderde bepalingen waren geschrapt, waren er ook veel nieuwe voor in de plaats gekomen (p. 37).

31 Kamerstukken II 1974/75, 12944, nr. 8, p. 1.

32 Handelingen II 1974/75, p. 2347. 


\section{Grondwetsinterpretatie}

Het voorgaande laat zien dat over de bindende kracht van de Grondwet voor de wetgever in het verleden wisselend is gedacht. Soms werd deze zelfs ronduit ontkend. De meeste staatsrechtelijke auteurs in de twintigste eeuw waren echter van oordeel dat de Grondwet de wetgever wel degelijk bindt. Struycken wees daarbij de weg, ook voor generaties na hem. Tegelijkertijd waren deze staatsrechtjuristen van oordeel dat de betekenis van de Grondwet niet in steen gebeiteld was. Wijzigden de omstandigheden, dan veranderde ook haar uitleg. Terwijl Lohman, Oppenheim en Krabbe betoogden dat de wetgever de Grondwet op grote schaal schond, waren rond het begin van de Eerste Wereldoorlog de meeste auteurs van oordeel dat een verkeerde uitleg van de Grondwet hen tot die conclusie had geleid. Een juiste grondwetsinterpretatie moest niet alleen acht slaan op haar historische betekenis, maar steeds een evenwicht vinden tussen heden en verleden. Zo luidde de kritiek van Struycken op Oppenheim, en zo luidde bijna vijftig jaar later ook de kritiek van Duynstee op Van der Hoeven. ${ }^{33}$ Deze benadering leidde er in de regel toe dat hoe ouder een grondwetsbepaling was, hoe minder betekenis bij haar uitleg toekwam aan haar bewoordingen en de (historische) bedoeling van de grondwetgever. ${ }^{34}$

De verklaring daarvoor ligt voor de hand. Vlak na haar vaststelling sluiten de tekst van de Grondwet en de bedoeling van de grondwetgever het best aan bij de wensen en noden van diegenen die geroepen zijn de Grondwet toe te passen. Beide elementen spelen dan ook een belangrijke rol bij haar uitleg. De grondwetscommentaren, die in Nederland traditioneel verschijnen vlak na belangrijke grondwetswijzigingen, illustreren dat. In de twintigste eeuw zijn dat het commentaar van Huart bij de grondwetsherziening van 1917 en 1922, ${ }^{35}$ van Dassen bij de grondwetsherziening van $1938,{ }^{36}$ van Duynstee bij de grondwetsherziening van $1953,{ }^{37}$ van Kortmann bij de grondwetsherziening van 1983 (en 1987), ${ }^{38}$ en het grondwetscommentaar onder redactie van Akkermans bij de grondwetsherziening van $1987 .{ }^{39} \mathrm{Al}$ deze commentaren besteden grote aandacht aan de tekst van de bepaling en hetgeen tijdens de parlementaire behandeling daarover is geschre-

34 Uiteraard bestaan op die hoofdregel uitzonderingen. Zo vond Buys, die in 1883 schreef over de Grondwet die bijna veertig jaar eerder voor het laatst was herzien, dat grondwetsbepalingen historisch moesten worden uitgelegd (J.T. Buys, De Grondwet. Toelichting en kritiek (deel I), Arnhem: Gouda Quint 1883, p. 93 en 324). Het is echter veelzeggend dat die opvatting hem direct op stevige kritiek kwam te staan van tijdgenoten (bijv. C.W. Opzoomer, In welken geest is onze Grondwet te verstaan?, Den Haag: Belinfante 1883, p. 9).

35 F.J.A. Huart, Grondwetsherziening 1917 en 1922 (diss. Leiden), Arnhem: Gouda Quint 1925.

36 J.M.H. Dassen, De Grondwetsherziening 1938 (diss. Nijmegen), Maastricht: Leiter-Nypels 1938.

37 F.J.F.M. Duynstee, Grondwetsherziening 1953, Deventer: Kluwer 1954.

38 C.A.J.M. Kortmann, De Grondwetsherziening 1983, Deventer: Kluwer 1983. Later verscheen van dezelfde hand De Grondwetsherzieningen 1983 en 1987.

39 P.W.C. Akkermans (red.), De Grondwet. Een artikelsgewijs commentaar, Zwolle: W.E.J. Tjeenk Willink 1987. 
ven en gezegd. ${ }^{40}$ Naarmate de tijd verstrijkt, neemt de overeenstemming tussen de gedachte van de grondwetgever en de wensen van grondwetstoepassers echter af. Daarmee verdwijnt ook de vanzelfsprekendheid om de Grondwet volgens de oude betekenis uit te leggen. Het voorgaande kan ook anders worden gesteld: hoewel het bindende karakter van de Grondwet voor de wetgever thans onbestreden is, leidt interpretatie ertoe dat na verloop van tijd de betekenis van de bedoeling van de grondwetgever voor de wetgever afneemt. Niet de betekenis van de Grondwet, maar die van de wil van de grondwetgever wordt dus langzaam minder belangrijk. ${ }^{41}$ In plaats daarvan wijzigt de betekenis van de Grondwet met veranderende opvattingen in de samenleving, met name zoals die tot uitdrukking komen in het overleg tussen regering en parlement.

De afname van de betekenis van de tekst van de Grondwet en van de bedoeling van de grondwetgever wordt in de praktijk echter niet volmondig erkend door de met interpretatie belaste ambten. ${ }^{42}$ Van der Hoeven liet in zijn dissertatie aan de hand van diverse voorbeelden zien hoe in het algemeen een veranderde uitleg in de praktijk wordt gerechtvaardigd. Sluit de historische betekenis van de Grondwet niet meer aan bij de actuele behoefte, dan vindt eerst een proces van 'rechtsverfijning' plaats. Daarbij worden bepalingen niet uitgelegd naar hun historische betekenis, maar wordt hun 'materiële bedoeling en strekking' opgespoord. ${ }^{43}$ Biedt deze interpretatietechniek onvoldoende ruimte aan de uitlegger, dan treedt een proces van formalisering op 'die normen tot technische begrippen terugbrengt', ${ }^{4}$ dat wil zeggen: tot begrippen die slechts een bepaalde vorm voorschrijven.

De wijze waarop werd betoogd dat de dualisering van het gemeente- en provinciebestuur verenigbaar was met het (in art. $125 \mathrm{Gw}$ vervatte) 'hoofdschap van de raad' kan een van die interpretatietechnieken illustreren. ${ }^{45}$ Bij de grondwetsherziening van 1983 werd - tegen de achtergrond van de toen geldende monistische bestuursstructuur van gemeenten en provincies - over die bepaling gezegd dat zij

40 Het feit dat de bedoeling van de grondwetgever vlak na de vaststelling van de Grondwet van belang is, blijkt bijv. uit art. $146 \mathrm{Gw}$-1814. Dit artikel bepaalde onder meer dat de 'authentieke uitlegging en verklaring der twijfelingen' waartoe toepassing van de Grondwet aanleiding zou kunnen geven, gedurende de eerste drie jaar na haar totstandkoming zouden worden opgedragen aan de Commissie die de Grondwet had ontworpen. In de Grondwet van 1815 keerde de bepaling niet terug. De Staatsregeling van 1801 bevatte een soortgelijke bepaling (art. 105).

41 Wil de grondwetgever zijn betekenis voor de wetgever vergroten, dan moet hij de Grondwet dus veelvuldig aanpassen, zodat deze bij de tijd blijft. Dat is een paradoxale conclusie. Met veelvuldige herziening toont de grondwetgever immers tegelijkertijd zijn relatieve onmacht.

42 Dat is uiteraard niet alléén de wetgever. Hoewel het toetsingsverbod de rechter verhindert de wet aan de Grondwet te toetsen, mag hij de Grondwet uitleggen in andere gevallen, bijv. bij de beoordeling van de grondwettigheid van een APV. Daarnaast legt de Raad van State de Grondwet op gezaghebbende wijze uit in zijn wetgevingsadviezen en voorlichtingen. Zowel bij de interpretatie van de Grondwet door de wetgever als bij die door de rechter en de Raad van State klinken daarnaast de 'geleerde' opvattingen van staatsrechtjuristen door.

43 Van der Hoeven 1958, p. 158.

44 Van der Hoeven 1958, p. 127.

45 Een uitgebreide beschrijving van de discussie over de grondwettigheid van de dualisering is te vinden bij J.L.W. Broeksteeg, 'Dualisering van het provincie- en gemeentebestuur', in: P.P.T. Bovend’Eert e.a., Constitutionele normen en decentralisatie, Deventer: Kluwer 2011, p. 105-151. 
moest duidelijk maken dat 'het laatste woord omtrent de hoofdlijnen van het te voeren beleid toekomt aan provinciale staten en de raad'. ${ }^{46}$ De Gemeentewet voldeed aan dat uitgangspunt, nu zij alle bestuursbevoegdheden aan de raad toekende. In de praktijk werd het college van B en W echter steeds belangrijker, met name door de toename van medebewindstaken, die in de praktijk veelal aan hem toevielen. Mede in het licht van die ontwikkeling wilde de regering rond de millenniumwisseling het gemeentebestuur dualiseren, waardoor het college van B en W een zelfstandige positie kreeg ten opzichte van de raad. Daartoe werd onder meer bepaald dat wethouders niet langer uit de raad afkomstig hoefden te zijn, en werden belangrijke bestuursbevoegdheden bij de raad weggehaald en aan het college toegekend. De vraag diende zich aan of deze wijzigingen verenigbaar waren met het grondwettelijk hoofdschap van de raad. ${ }^{47}$ De regering beantwoordde die vraag bevestigend en maakte daarbij gebruik van wat een rechtsverfijnende interpretatie van de Grondwet kan worden genoemd. Zij was van oordeel 'dat de Grondwet de wetgever niet verplicht het lokale bestuursmodel op een bepaalde wijze in te richten. Wel verplicht de Grondwet de wetgever het lokale bestuursstelsel zo in te richten dat de raad materieel invulling kan geven aan de centrale positie die hem door de grondwetgever in het lokale bestuursmodel is toebedacht.' ${ }^{48}$ Voor de regering was zo voor de grondwettigheidsvraag niet beslissend of na de dualisering bepaalde bevoegdheden aan de raad waren toegekend, maar of de raad ten aanzien van het college over voldoende 'politieke beïnvloedings- en verantwoordingsmechanismen' beschikte. ${ }^{49}$ En die mechanismen waren er: het college was verantwoording verschuldigd aan de raad, de raad had het recht inlichtingen te vragen aan het college, en kon - via de vertrouwensregel een wethouder tot ontslag dwingen en uiteindelijk zelfs ontslaan. ${ }^{50}$ Het parlement stemde uiteindelijk in met de dualisering van het gemeentebestuur. Hoewel daarmee invulling werd gegeven aan het in artikel $125 \mathrm{Gw}$ neergelegde hoofdschap van de raad, lijkt die invulling een andere te zijn dan de grondwetgever van 1983 voor ogen had.

\section{Grondwetsinhoud}

Pas als grondwetsinterpretatie niet het gewenste resultaat oplevert, wordt in Nederland grondwetsherziening overwogen. Zulke herzieningen fungeren niet als breekijzer, waarmee veranderingen in staatsbestel of samenleving worden geforceerd, maar hebben tot doel om breedgedragen opvattingen in de samenleving, zoals die hoofdzakelijk tot uitdrukking komen in het overleg tussen regering en parlement, te formaliseren. Zo luidt inmiddels ook het grondwetsherzieningsbeleid, zoals blijkt uit de kabinetsreactie op het rapport van de Staatscommissie Grondwet uit 2010. Minister Donner verwoordde dat beleid als volgt: 
'Aanpassingen [van de Grondwet; JS] moeten voortvloeien uit ontwikkelingen die reeds in bestaande regelgeving of andere besluiten met voldoende draagvlak zijn bevestigd, dan in andere zin breed door de samenleving worden gedragen. Er moet, met andere woorden, een dringende behoefte aan bestaan en het moet gaan om zaken die voldoende constitutionele rijpheid vertonen. ${ }^{51}$

Opvallend is daarbij dat het kabinet de vraag of een norm in de Grondwet moet worden opgenomen, niet (mede) afhankelijk stelt van de aard van de norm. Er bestaat bij de regering, het parlement of de Raad van State dan ook geen duidelijke visie over de onderwerpen die vanwege hun aard per se in de Grondwet geregeld moeten worden. ${ }^{52}$ Een formeel grondwetsidee, zoals Van der Tang dat noemt, ontbreekt. ${ }^{53}$ Bij de grondwetsherziening die leidde tot de deconstitutionalisering van de aanstellingswijze van de burgemeester en van de commissaris van de Koning, verklaarde de minister dan ook onomwonden 'dat er geen criteria bestaan voor constitutionalisering en deconstitutionalisering. ${ }^{54}$

Ook staatsrechtjuristen schrijven weinig over de vraag welke onderwerpen in de Grondwet geregeld zouden moeten worden. Doen zij dat wel, dan ligt aan hun bespiegelingen vaak evenmin een duidelijke visie ten grondslag over welke normen in de Grondwet horen te worden opgenomen. ${ }^{55}$ Men blijft doorgaans steken bij de opmerking dat de Grondwet 'de fundamenten van het constitutionele bestel' hoort te bevatten. ${ }^{56}$ Het ontbreken van een breed gedeelde opvatting over wat tot die fundamenten behoort, leidt er in de praktijk toe dat de wetgever alleen genoodzaakt is de Grondwet te wijzigen als hij een regeling wil treffen die evident onverenigbaar is met een concrete grondwetsbepaling.

De wijze waarop Bonaire, Sint Eustatius en Saba zijn opgenomen in het land Nederland illustreert de gevolgen daarvan in de praktijk. Na de wijziging van 2010 bepaalde het Statuut dat de genoemde eilanden 'onderdeel [zijn] van het staatsbestel van Nederland'. ${ }^{57}$ Daarmee was echter nog niet bepaald welke status deze eilanden binnen het Nederlandse staatsbestel zouden krijgen. De regering wilde deze gebieden de status van openbaar lichaam in de zin van artikel $134 \mathrm{Gw}$

51 Kamerstukken II 2011/12, 31570, nr. 20, p. 4. De uitgangspunten waren voor het kabinet aanleiding om geen van de aanbevelingen van de staatscommissie op te volgen. Het grote aantal minderheidsstandpunten maakte volgens het kabinet duidelijk dat haar voorstellen 'onvoldoende constitutionele rijpheid' vertoonden (p. 11-12).

52 Vgl. C.A.J.M. Kortmann, 'Wegwerprecht', NJB 1998, p. 206 ('Is artikel 131 Gw van fundamenteel staatsrechtelijk belang? Ja, aldus de Raad van State, neen volgens de regering. Interessant is dat beide niet uitleggen waarom dat het geval is.')

53 G.F.M. van der Tang, 'Constitutie en Grondwet', RegelMaat 2003, p. 236. Hij wijst erop dat het gebrek aan een dergelijk idee ook tot triviale grondwetsherzieningen leidt. Ik laat dat aspect hier buiten beschouwing. Zie ook M. Nap, 'Criteria voor grondwetsherzieningen', RegelMaat 2020, p. 280.

54 Kamerstukken I 2001/02, 27551, nr. 56a, p. 4.

55 Zie bijv. de bijdragen in het NJB-themanummer over '150 jaar Grondwet' uit 1998 (afl. 5) en enige jaren later C.A.J.M. Kortmann, 'Uit of in de Grondwet?', RegelMaat 2002, p. 75-82.

56 Kortmann 1998, p. 206.

57 Art. 1, eerste lid, Statuut (oud). Zie daarover Kamerstukken II 2009/10, 32213 (R 1903), nr. 4. 
geven. ${ }^{58}$ In zijn advies over het wetsvoorstel stemde de Raad van State daarmee in, maar voegde daaraan toe dat die status slechts een 'tussenstap' kon zijn in afwachting van 'een meer definitieve voorziening in de Grondwet'. Zo'n voorziening was te meer vereist omdat 'artikel 134 niet primair is geschreven met het oog op territoriale decentralisatie'. Volgens de Raad moest daarom gelijktijdig met de behandeling van het bedoelde wetsvoorstel een grondwetsherzieningsvoorstel in behandeling worden gebracht dat 'de essentialia van de toekomstige positie van Bonaire, Sint Eustatius en Saba, als openbare lichamen van territoriale decentralisatie, binnen het Nederlandse staatsverband' regelde. ${ }^{59}$ De regering had echter minder haast. Ook volgens haar kon artikel $134 \mathrm{Gw}$ slechts een tijdelijke grondslag bieden, maar de 'meerwaarde' van het onmiddellijk starten van een grondwetswijzigingsprocedure erkende zij niet. Eerst zou een evaluatie moeten plaatsvinden. ${ }^{60}$ Het grondwetsherzieningsvoorstel werd uiteindelijk in 2011 ingediend. ${ }^{61}$ In de memorie van toelichting schreef de regering dat artikel $134 \mathrm{Gw}$ niet is geschreven voor territoriale decentralisatie en dus geen grondwettelijke waarborgen bevat 'die kenmerkend zijn voor en tevens zijn voorbehouden aan de territoriaal gedecentraliseerde bestuurslichamen die de Grondwet kent'. ${ }^{62}$ Het nieuwe artikel 132a Gw bevatte deze waarborgen wel. Het kon in 2017 worden afgekondigd. ${ }^{63}$ Omdat een duidelijk idee ontbrak over welke normen in de Grondwet horen te worden opgenomen, kon de wetgever dus - zonder voorafgaande grondwetswijziging - het bestuur van Bonaire, Sint Eustatius en Saba zelf regelen. ${ }^{64}$ Hoewel het belang van een bijzondere grondwettelijke verankering vanaf het begin door de regering en de Raad van State werd onderschreven, had de wetgever daardoor in 2010 de vrije hand bij het regelen van de status van de Caribische eilanden. ${ }^{65}$

58 In de aanloop naar die Statuutswijziging had de Raad van State dat ook gesuggereerd. Hij wees er toen op dat op grond van die bepaling een halve eeuw eerder ook het bestuur over de Zuidelijke IJsselmeerpolders (1955), Elten en Tudderen (1949) was geregeld. Dat kon toen, aldus de Raad, omdat deze gebieden niet 'pasten in de gewone structuur van de territoriale decentralisatie'. Een grondwetswijziging was volgens de Raad dus 'niet strikt vereist'. 'Op den duur is grondwetswijziging wel wenselijk', vervolgde de Raad, 'om elk misverstand of elke onduidelijkheid weg te nemen' (Kamerstukken 2006/07, 30800-IV, nr. 3 (bijlage), p. 21-22).

59 Kamerstukken II 2008/09, 31954, nr. 4, p. 2.

60 Kamerstukken II 2008/09, 31954, nr. 4, p. 3. De Wet openbare lichamen Bonaire, Sint Eustatius en Saba bereikte in 2010 het Staatsblad (Stb. 2010, 345).

61 Kamerstukken II 2011/12, 33131, nr. 1 e.v.

62 Kamerstukken II 2011/12, 33131, nr. 3, p. 2.

63 Stb. 2017, 426.

64 Een ander voorbeeld biedt de Werdegang van het regeringsvoorstel uit 1996 om zelfstandige bestuursorganen in de Grondwet te regelen. De Raad van State vond regeling daarvan in de Grondwet 'niet verantwoord', omdat de discussie over zulke bestuursorganen 'nog niet was uitgekristalliseerd' (Kamerstukken II 1997/98, 25629, B, p. 1). Het voorstel werd uiteindelijk ingetrokken (Kamerstukken II 1998/99, 25629, nr. 6). Nap 2020, p. 278 schreef in dit verband dat volgens de Raad van State de rigiditeit van de Grondwet kennelijk haar schaduw vooruit moet werpen.

65 Ook de rekkelijke uitleg van art. $134 \mathrm{Gw}$ valt op. Regering en Raad van State zijn het erover eens dat de bepaling niet is geschreven als grondslag voor territoriale decentralisatie, maar zien er geen probleem in haar toch als tijdelijke grondslag daarvoor te gebruiken. 


\section{Slot}

In 2010 adviseerde de Staatscommissie Grondwet over de mogelijkheden om de juridische betekenis van de Grondwet te versterken. Zij sprak in dit verband over het vergroten van haar 'normatieve karakter' of haar 'rechtskracht'. ${ }^{66}$ Met dat doel voor ogen stelde zij onder meer voor een algemene bepaling in de Grondwet op te nemen die verklaart dat Nederland een democratische rechtsstaat is, en adviseerde zij constitutionele toetsing mogelijk te maken. In deze bijdrage hoop ik echter te hebben laten zien dat de normatieve betekenis van de Grondwet niet alleen afhangt van haar inhoud. Zij wordt ook - en misschien wel: vooral bepaald door de Nederlandse (juridische) grondwetscultuur. Ik heb van die cultuur drie met elkaar samenhangende elementen beschreven. De Grondwet bindt de wetgever. Bij de uitleg van haar bepalingen moet echter hun leeftijd worden meegewogen. Hoe ouder een bepaling, hoe minder gewicht haar bewoordingen en de bedoeling van de grondwetgever in de schaal leggen. Zo vermindert na verloop van tijd de betekenis van de Grondwet voor de wetgever. Haar betekenis wordt verder gerelativeerd doordat geen breed gedeelde visie bestaat over welke normen per se in de Grondwet moeten worden opgenomen. Daardoor wordt de betekenis van de Grondwet als normerend kader voor de wetgever gerelativeerd. Het verankeren van de democratische rechtsstaat en het mogelijk maken van constitutionele toetsing alléén zullen daaraan niet of nauwelijks weerstand kunnen bieden. 